\title{
Audit Committee Attributes and Financial Reporting Quality of the State-owned Commercial Enterprises in Kenya
}

\author{
Jack Kasole Wasonga Winnie Nyamute Nixon Omoro Lisiolo Lishenga \\ School of Business, University of Nairobi, P.O. Box 30197, 00100 Nairobi, Kenya
}

\begin{abstract}
The research is financed by the PhD Candidate
Abstract

The study examines the relationship between audit committee attributes and financial reporting quality of Stateowned Commercial Enterprises in Kenya. An analysis was done on annual reports and financial statements for 122 state-owned commercial for the period between 2008 and 2018. The results indicate that audit committee attributes has statistically significant relationship with financial reporting quality of State-owned Commercial Enterprises in Kenya. Results further reveal the audit committee independence has statistically significant and negative relationship with financial reporting whereas audit committee qualification, size and number of meetings held in a financial year had statistically significant and positive relationship with accrual quality. While audit committee independence and qualification exhibited statistically significant positive and negative relationship with qualitative characteristics respectively, it was evident that audit committee attributes had no significant relationship with timeliness in reporting. It is therefore, concluded that audit committee attributes impact financial reporting quality in State-owned Commercial Enterprises in Kenya requiring the appointing authorities to appoint audit committee members with the right skill mix and qualification to realize value addition services and improve financial reporting oversight.
\end{abstract}

Keywords: Audit Committee Attributes, Financial Reporting Quality, State-owned Commercial Enterprises

DOI: $10.7176 /$ RJFA/11-14-12

Publication date:July $31^{\text {st }} 2020$

\section{Introduction}

High profile accounting scandals (Enron; WorldCom) has placed the role of audit committee at the fight against fraudulent financial reporting, hence increased demand for enhanced corporate governance mechanisms (Mohiuddin \& Karbhari, 2010). Stakeholders and investors depend on the quality of financial information disclosures in financial statements and annual reports. Bedard and Gendron (2010) observe that regulators expect independent audit committee with frequent meetings to strengthen quality of financial information while maintaining/strengthening financial reporting quality (FRQ). Audit committee is viewed to improve quality of financial information by providing oversight on financial reporting process leading to investor confidence (Bedard \& Gendron, 2010). Further, it is argued that audit committee provide oversight while protecting shareholders' interests in organizations (Chen et. al., 2008; and Turley \& Zaman, 2007) and no indication on relationship with audit committee attributes and financial reporting quality (Wallace \& Nasser, 1995) of state-owned commercial enterprises.

Different theories have been used in audit committee research drawing from various perspectives including legal, economics, psychology and sociology. While legal perspective observes that audit committee roles are prescribed by laws and regulations, agency theory suggests that monitoring of management by audit committee strengthens financial information and reporting process quality (Bedard \& Gendron, 2010). The expertise paradigm as one of the psychological perspectives and institutional theory has affirmed the linkage between audit committee qualification and financial reporting quality (Bedard \& Chi, 1993). Turley and Zaman (2007) assert that audit committee may have influence as supported by power theory on and be affected by use of authority by members and other stakeholders drawing power from different sources.

\subsection{Audit Committee Attributes}

Audit committee attributes has become a critical pillar in corporate governance structure owing to increased changes in regulatory requirements and demand by stakeholders. While DeZoort et al., (2002) defines audit committee attribute as a variable or trait that impact on the effectiveness of an audit committee, they view audit committee as a team with competent members with expertise and resources to protect shareholder's interest by ensuring dependable financial reporting, internal controls and risk management through diligent oversight efforts. This is further supported by Sarbanes Oxley Act (SOX) $(2002,205)$ which assert that audit committee is a team established by and among the board of directors of a corporation for the purpose of providing oversight over accounting and financial reporting processes and audits of financial statements.

Audit committee attributes' role cannot be overemphasized and SOX (2002) assert that independent audit committee enhances effective financial reporting monitoring as it is charged with overseeing the financial reporting process as well as oversight over financial reporting. The role of audit committee is observed as assisting the board 
on oversight over integrity of financial statements, company's compliance with legal and regulatory requirements, determination of independent auditor's qualification and independence, and performance of the corporation's internal audit and the independent auditor through strong institutional structures as supported by institutional theory (Woodlock, 2006). Public Finance Management Act 2012 and regulation 2015 establishes audit committees in the state-owned commercial enterprises prescribing its structure, role and responsibilities.

Different researchers have applied various methodologies to measure impact of audit committee attributes on financial reporting quality. Mohiuddin and Karbhari (2010) used audit committee attributes of independence, qualification/financial knowledge of members, size and frequency of meetings to measure audit committee effectiveness. Woodlock (2006) further observes that effective oversight of audit committee begins with competence and independence of members. DeZoort et al. (2002) asserts that an independent audit committee protects stakeholders' interest through guaranteeing reliable financial reporting, effective internal control and quality risk management. The study uses audit committee attributes of independence, qualification of members, size and number of meetings held annually as used by Mohiuddin and Karbhari (2010) to evaluate the impact on the identified variables.

\subsection{Financial Reporting Quality in State-owned Commercial Enterprises}

The quality of financial reporting has remained a major concern among practitioner, regulators and other users of financial information as it is the principal means of communicating financial performance to stakeholders. However, researchers, practitioners and regulators are not in agreement to a perfect delineation of financial reporting quality (Pomeroy \& Thomton, 2008). Martinez-Ferrero (2014) defines financial reporting quality as the faithfulness of the information as reflected in the financial reporting process. SOX (2002) require audit committee to converse the quality of financial reporting methods and not their acceptability but fail to describe what constitute the quality financial reporting. The IASB (2008) in its conceptual framework defines financial reporting quality to that which meets the objectives and qualitative characteristics of financial reporting.

Beasley (1996) observe that financial reporting provides information about the management's stewardship, entity's assets, liabilities, equity, income and expenses, contributions and distributions to owners. IASB (2010) posit that relevance and faithful representation of financial information are primary qualitative characteristics of financial statements and financial reporting is premised in providing information useful for decision making in investment, credit, and similar resource allocation. Accrual and value relevance models focused on earnings quality measurement and those fixated on specific elements in annual reports and methods operationalizing qualitative characteristics have been applied (Bushman \& Smith, 2001; Healey \& Palepu, 2001; Lambert et al., 2007).

Some scholars have argued that accrual models only use financial information while ignoring non-financial information from audited financial statements and annual reports (Vantendeloo and Vansstrealen, 2005). Further, it has been advanced that earning persistence, timeliness in reporting, audit fees charged, disclosure quality and adoption and compliance with the international financial reporting standards' (IFRS) requirements actuate financial reporting quality (Biddle and Hillary, 2006 and Lambert et al., 2007). The studies further reveal that financial reporting quality is still and remains the main source of external information to numerous financial reporting stakeholders. State-owned commercial enterprises in Kenya adopted the International Financial Reporting Standards as their financial reporting framework.

\subsection{State-owned Commercial Enterprises}

State agencies are incorporated bodies separate from mainstream civil service for driving public service delivery and viewed as part of State dealing with production, ownership, sale, provision, delivery or allocation of goods and services by and for the government or its citizens, whether national, regional or local or municipal (Barlow, Reohrich \& Wright, 2010). Dooren (2006) assert that the legal aspect including financial and functional should be considered in defining public sector. However, it is argued that the only approach to increase economic benefits is to elevate level of productivity while improving management quality where government require to tap prospective manpower, material and financial resources and making full use of available resources for production and operation (Guoming, 2007).

State-owned commercial enterprises (SOCEs) have been defined as organisations established singly or through majority shareholding by government and/or its institutions or a body incorporated through an Act of parliament to meet commercial objectives (OECD, 2005a,:36; Wamalwa, 2003 \& PTPR, 2013). SOCEs have continued to inhibit weak and ineffective audit committees and poor financial reporting leading to pilferages. This has been manifested through increased financial restatements (Ogoro \& Simiyu, 2015), Public Investment Committee (PIC), Public Accounts Committee (PAC) and Auditor General's reports (2013-14, 2014-15, 2015-16, 2016-17 \& 2016-2018) revealing malpractices in financial reporting. In addition, scandals have been witnessed in institutions such as Mumias Sugar and Kenya Pipeline resulting to questions of competence, capacity and effectiveness of audit committees to provide strong oversight on governance, control and quality financial reports. 
Despite various financial reporting framework and legislations enacted, issues of governance, accountability, efficiency and effectiveness in utilization of public resources have been a major concern in the public sector institutions and it has been enhanced through the constitution, Public Finance Management Act 2012 and published audit committee guidelines (PSASB, 2015) for establishment of audit committees in the public sector. Insofar as governance structures including the establishment of audit committees and annual audit by the Office of the Auditor General no improvement in financial reporting quality has been experienced. This led to numerous questions on integrity on financial reports presented. Prior studies (Bedard \& Gendron, 2010) have in the past concentrated on listed companies and private sector entities and therefore, making State-owned Commercial Enterprises to be selected for this study.

\subsection{Research Problem}

Financial reporting quality has attracted much attention from regulators, shareholders, researchers, investors and practitioners and questions on financial reporting quality and other governance structures have been raised and evidence has linked quality of financial reporting with audit committee attributes in the public listed firms (Warren \& Reeve, 2004; Bedard \& Gendron, 2010). This has not been reflected in the State-owned enterprises where poor quality of financial reports has been observed. Francois and Kyle (2011) and Schoar (2003) and Bamber et al, (2010) posit that audit committee size as an attribute impact financial reporting quality positively while audit committee independence shows no positive relationship with financial reporting quality as confirmed by Sehu and Bello (2013).

Financial reporting quality is envisaged to exist in the state-owned commercial enterprises (SOCEs) due to oversight of audit committee in these organisations. Supported by agency theory perspective, audit independence impact financial reporting quality (Kalbers \& Fogarty 1998; Wallace \& Naser 1995). Weak audit committees has led to inaccurate financial reporting, imprudent application of resources and poor corporate governance as evidenced by Public Accounts and Public Investment Committees' reports presented in parliament (Parliamentary Hansard) questioning accountability, information integrity, role of audit committee and internal controls over financial reporting process. Despite existing legal instruments, circulars from the National Treasury and code of governance for state corporations and International Financial reporting Standards (IFRS) requiring effective audit committee, very limited progress has been experienced (Circular no. 16 of 2005; PFMA, 2012; PFM Regulations, 2015 \& MCGSC, 2015). The study therefore, sought to address the research question: what is the effect of audit committee attributes on financial reporting quality in state-owned commercial enterprises in Kenya?

\section{Literature Review}

Existing findings links audit committee attributes with financial reporting quality in organisations. Best et al. (2001) investigated the association between attributes of audit committee and financial reporting quality and used survey responses from audit committee chairperson, non-executive director and chief audit executive of a sample of Australian listed companies and found no positive relationship between audit committee attributes and financial reporting quality. In the USA, Abbott and Parker (2000) investigated the relationship between independent audit committee and financial reporting quality in 78 firms under SEC regulations and 78 non-sanctioned firms based on the Blue Ribbon Committee (1999) recommendations and observed that firms with independent audit committees are likely to improve financial reporting quality.

Using 114 internal auditors of public companies in the USA, Raghunandan et al. (2001) did a study on the association between audit committee attributes and the committee's interaction with internal auditing. The study finds that audit committee with at least one member having accounting or finance qualification is likely to be effective by holding meetings with chief audit executive while providing private access and reviewing internal audit reports and concludes that companies with financial reporting problems are less likely to have members with an accounting qualification. However, Isakulchai (2015) affirm the relationship between audit committee attributes and quality financial reporting.

Song and Windram (2000) examined the audit committee attributes in the United Kingdom on their role of overseeing financial reporting and used binary logit regression model to analyze financial reporting for the period between 1991 and 2000 and find that audit committee independence reduces financial reporting problems while corporations with reporting difficulties had less common audit committee meetings. Beasley et al. (2000) in their study on possible fraud in technology, financial services and health-care industries observe no relationship between audit committee size and financial reporting quality but contend that firms with audit committee having more meetings experience less qualified reports.

\section{Data Analysis and Results}

The objective of the study examined the relationship between audit committee attributes and financial reporting quality of State-owned Commercial Enterprises in Kenya (SOCE). The audit committee attributes comprised of independence (AC_IND), qualification (AC_QUA), size (AC_SIZ) and number of meetings held in a year 
(AC MEET) whereas accrual quality (AQ), qualitative characteristics (QC) and timeliness in reporting (TR) were applied in the test as measures of financial reporting quality (FRQ). The data were obtained from the published audited financial statements and annual reports of the respective state-owned commercial enterprises for the period between 2008 and 2018. The following equation was used in determining the relationship.

$\mathrm{FRQ}_{\mathrm{it}}=\beta_{0}+\beta_{1} \mathrm{AC} \_\mathrm{IND}_{\mathrm{it}}+\beta_{2} \mathrm{AC} \_\mathrm{QU} \mathrm{A}_{\mathrm{it}}+\beta_{3} \mathrm{AC} \_\mathrm{SIZ}_{\mathrm{it}}+\beta_{4} \mathrm{AC} \_\mathrm{MEET}_{\mathrm{it}}+\mathrm{u}_{\mathrm{it}}$

Where:

FRQ ${ }_{\text {it }}$ : $\quad$ Financial Reporting Quality indicator for $i$ SOCE in year $t$

$\beta_{0}$

$\beta_{1-4}$ Intercepts

AC_IND ${ }_{\text {it }}$ :

Coefficient of independent variables

AC_QUA:

AC SIZ:

AC_MEET:

$\mathrm{u}_{\mathrm{it}}$

Audit Committee Independence for i SOCE in year $\mathrm{t}$

Audit Committee Qualification for $i \mathrm{SOCE}$ in year $t$

Audit Committee Size for $i$ SOCE in year $t$

Audit Committee Meetings held for $i$ SOCE in year $t$ error term.

\subsection{Descriptive Statistics}

The research employed descriptive statistics comprising of mean, median, standard deviation, minimum and maximum to analyse and summarize the study variables. The data covers 122 State-owned Commercial Enterprises for the period between 2008 and 2018. Table 3.1 below reports the mean, standard deviation, maximum, minimum and the number of observations for the period between 2008 and 2018. The analyses of the descriptive statistics for all study variables for the number of observations are shown in the Table 1.

Table 1: Descriptive Statistics for Audit Committee Attributes

\begin{tabular}{|l|r|r|r|r|r|r|}
\hline Variable & \multicolumn{1}{l|l}{ N } & \multicolumn{1}{l|}{ Mean } & \multicolumn{1}{l|}{ S.D. } & \multicolumn{1}{l|}{ Min } & \multicolumn{1}{l|}{ Mdn } & Max \\
\hline Audit Committee Independence & 1342 & 2.95 & 0.63 & 2 & 3 & 5 \\
\hline Audit Committee Qualification & 1342 & 1.81 & 0.59 & 1 & 2 & 3 \\
\hline Audit Committee Size & 1342 & 5.11 & 0.49 & 4 & 5 & 6 \\
\hline Audit Committee Meetings & 1342 & 6.46 & 1.18 & 3 & 6 & 9 \\
\hline
\end{tabular}

The study findings in Table 1 shows that the size of Audit Committee in the State-owned Commercial Enterprises in Kenya (SOCEs) ranges between 4 and 6 members, with an estimated mean of five (mean=5.11) members. Further, the results shows that the number of independent members in Audit Committees range between 2 and 5 members with an estimated mean of 2 (mean=2.95) members while those with accounting/finance expertise 1 and 3 members with a mean of 2 (mean=1.81) members. The table further indicates during the study period, the number of audit committee meetings held in a year ranged between 3 and 9 with a mean of 6 (mean=6.46) meetings in year.

\subsection{Hypothesis Testing}

This led to formulation of the hypothesis stating that audit committee attributes has no significant relationship with the financial reporting quality of state-owned commercial enterprises in Kenya which was supported by the analysis of the literature and various theoretical reasoning.

$\mathbf{H}_{1}$ : Audit Committee Attributes has no significant relationship with Financial Reporting Quality of State-owned Commercial Enterprises in Kenya.

Three additional hypotheses were developed to test the effect of audit committee attributes on each of the dependent variables of financial reporting quality. The three sub hypotheses are as follows:

$\mathrm{H}_{1 \mathrm{a}}$ : Audit Committee Attributes has no significant relationship with Accrual Quality in State-owned Commercial Enterprises in Kenya

$\mathrm{H}_{1 \mathrm{~b}}$ : Audit Committee Attributes has no significant relationship with Qualitative Characteristics in State-owned Commercial Enterprises in Kenya

$\mathrm{H}_{1 \mathrm{c}}$ : Audit Committee Attributes has no significant relationship with Timeliness Reporting in State-owned Commercial Enterprises in Kenya

This study uses panel data analysis technique since the panel data allows for the control of individual heterogeneity (Fitrianto and Musakkal, 2016).

Tests on the hypotheses were as follows:

H1: Audit Committee Attributes has no significant relationship with Financial Reporting Quality of State-owned Commercial Enterprises in Kenya. 


\subsection{Diagnostic Tests}

3.3.1 Multicollinearity

Panel multicollinearity test was conducted to eliminate possibility of having collinear explanatory variables used in the study. Based on the results in Table 2, Variance Inflation Factor (VIF) $<10$ and the mean VIF is 1.11 , an indication that the independent variables were not highly correlated, hence no existence of multicollinearity. This is an indication of the suitability of the variables for panel data regression analysis.

Table 2: Multicollinearity Test Results (Mean VIF=1.11)

\begin{tabular}{|l|l|l|}
\hline Variable & VIF & $1 /$ VIF (Tolerance) \\
\hline Audit Committee Qualification & 1.23 & 0.815561 \\
\hline Audit Committee Independence & 1.09 & 0.917587 \\
\hline Audit Committee Size & 1.08 & 0.923554 \\
\hline Audit Committee Meetings & 1.06 & 0.943295 \\
\hline
\end{tabular}

3.3.2 Heteroscedasticity

Breusch-Pagan / Cook-Weisberg test for Heteroskedasticity was used. The null hypothesis suggests the presence of constant variance which means data is homoscedastic. The p-value is 0.5008 which is not significant and therefore the null hypothesis is rejected. Therefore, the dataset has no heteroskedastic variances.

3.3.3 Serial Correlation Test

Wooldridge test for autocorrelation in panel data was used. The null hypothesis indicates that there was no serial correlation. Serial correlation causes the standard errors of the coefficients to be smaller than they actually are and higher R-squared. A significant test statistic indicates the presence of serial correlation. Results of Wooldridge test (Table 3 ) indicate that the problem of autocorrelation is not present.

Table 3: Wooldridge Test for Autocorrelation

\begin{tabular}{|l|l|}
\hline Test Statistic & Prob $>$ F \\
\hline 0.473 & 0.4930 \\
\hline
\end{tabular}

Null Hypothesis: There is no serial correlation

3.4 Hausman Specification Test

To decide between fixed or random effects, Hausman test was used where the null hypothesis is that the preferred model is random effects verses the alternative the fixed effects (Green, 2008). The test basically tests whether the unique errors $\left(\mathrm{u}_{\mathrm{i}}\right)$ are correlated with the regressors; the null hypothesis is they are not. Table 4 shows the results of Hausman test.

Table 4: Hausman Test to Choose Fixed or Random Effect

\begin{tabular}{|l|l|}
\hline Chi-square Statistic & P-Value \\
\hline 0.02 & 0.8831 \\
\hline
\end{tabular}

Null Hypothesis: The appropriate model is Random effects.

3.4.1 Random Effect Panel Regression Analysis

The study examined the influence of audit committee attributes on the financial reporting quality in State-owned Commercial Enterprises in Kenya. Results of Hausman tests revealed that a random effects model was appropriate (Table 4). The results of panel regression analysis are shown in Table 5. Random Effect model was run with the robust option to ensure that the covariance estimator can handle Heteroskedasticity of unknown form to test the first hypothesis.

Table 5 provides information about model regression coefficients. The results show a significant effect of both Audit Committee Independence $(\beta=0.0148, \mathrm{p}<0.01)$ and Audit Committee Qualification $(\beta=-0.0138, \mathrm{p}<0.01)$ on Financial Reporting Quality (FRQ) for the random effect model. The random effects models further reveal that the relationship between Financial Reporting Quality and Audit Committee Size is negative and not statistically significant. Similarly the relationship between Financial Reporting quality and Audit Committee Meetings held in a year is negative and not statistically significant. The value of Wald Chi-Square statistic (Wald chi2 (4)) is 9.95 and Prob $>$ chi2 is 0.0412 . The Wald test is used to test the hypothesis that at least one of the predictors' regression coefficients is not equal to zero. 
Table 5: Results of the Random Effect model for Panel Regression Analysis, Dependent Variable: Financial Reporting Quality

\begin{tabular}{ll}
\hline & $(1)$ \\
VARIABLES & Random Effects \\
\hline AC_IND & $0.0148^{* *}$ \\
AC_QUA & $(0.00624)$ \\
& $-0.0138^{* *}$ \\
AC_SIZ & $(0.00657)$ \\
& -0.00552 \\
AC_MEET & $(0.00688)$ \\
Constant & $-4.90 \mathrm{e}-06$ \\
& $(8.12 \mathrm{e}-05)$ \\
\hline Observations & $0.143 * * *$ \\
R-Squared & $(0.0387)$ \\
Wald chi2 (4) & 1,165 \\
Prob $>$ chi2 & 0.0695 \\
Number of SOCE_ID & 9.95 \\
\hline
\end{tabular}

Robust standard errors in parentheses

$* * * \mathrm{p}<0.01, * * \mathrm{p}<0.05, * \mathrm{p}<0.1$

The number in the parentheses indicates the degrees of freedom of the Chi-Square distribution used to test the Wald Chi-Square statistic and is defined by the number of predictors in the model (4). The results from the Wald Chi-Square test indicate that the model as a whole is (all the predictors' regression coefficients taken jointly) significant. R-squared $\left(\mathrm{R}^{2}\right)$ was 0.0695 which suggests that audit committee attributes accounts for $6.95 \%$ of the variance in financial reporting quality. Based on the results as indicated, hypothesis was therefore rejected.

The following sub-hypothesis was examined to get more insight on the relationship between audit committee attributes and financial reporting quality in the state-owned commercial enterprises in Kenya.

$H_{l a}:$ Audit Committee Attributes has no significant relationship with Accrual Quality in State-owned Commercial Enterprises in Kenya

\subsection{Diagnostic Tests}

\subsubsection{Multicollinearity}

Based on the results of Table 6, Variance Inflation Factor (VIF) $<10$ and the mean VIF is 1.11 , an indication that the independent variables were not highly correlated, hence no existence of multicollinearity. This is an indication of the suitability of the variables for panel data regression analysis.

Table 6: Multicollinearity Test Results (Mean VIF=1.12)

\begin{tabular}{|l|l|r|}
\hline Variable & VIF & 1/VIF \\
\hline AC_QUA & 1.23 & 0.812618 \\
\hline AC_IND & 1.09 & 0.915856 \\
\hline AC_SIZ & 1.09 & 0.921595 \\
\hline AC_MEET & 1.06 & 0.941357 \\
\hline
\end{tabular}

\subsubsection{Heteroscedasticity}

Table 7 presents the results of Breusch-Pagan / Cook-Weisberg test for Heteroskedasticity with a test statistic of 821.87 ( $\mathrm{p}$-value $=0.0000$ ) which is significant, an indication that we do have heteroscedasticity in the residual of this regression model.

Table 7: Breusch-Pagan test for Heteroskedasticity

\begin{tabular}{|l|r|}
\hline Statistic & p-value \\
\hline 821.87 & 0.0000 \\
\hline
\end{tabular}


3.6 Panel Regression Analysis

Table 8: Results of Panel Regression Analysis, Dependent Variable: Accrual Quality

$\frac{\text { VARIABLES }}{\text { AC IND }}$

Model 1

AC IND

$-30.64 * *$

AC_QUA

AC_SIZ

AC_MEET

Constant

Robust standard errors in parentheses

$* * * \mathrm{p}<0.01, * * \mathrm{p}<0.05, * \mathrm{p}<0.1$

The study examined the influence of audit committee attributes on accrual quality in State-owned Commercial Enterprises in Kenya. Results of the panel regression analysis as shown in shown in Table 8 reveal a statistically significant relationship between audit committee independence $(\beta=-30.64, p<0.05)$, audit committee qualification $(\beta=35.54, p<0.05)$, audit committee size $(\beta=181.0, p<0.01)$, audit committee meetings held in a year $(\beta=89.42$, $\mathrm{p}<0.05)$ and accrual quality. However, the results also show that the relationship between accrual quality and audit committee independence is negative and statistically significant $(\beta=-30.64, p<0.05)$ while the relationship between accrual quality (AQ) and AC_QUA is positive and statistically significant $(\beta=35.54, p<0.05)$. R-squared $\left(R^{2}\right)$ was 0.064 which suggests that audit committee attributes accounts for $6.4 \%$ of the variance in the accrual quality which is a proxy for financial reporting quality. The hypothesis examined the relationship between accrual quality (AQ) (dependent variable) and audit committee attributes in the state-owned commercial enterprises in Kenya by suggesting that audit committee attributes has no significant relationship with accrual quality in state-owned commercial enterprises in Kenya. The results however, indicate that audit committee attributes have a significant relationship with accrual quality and we therefore, reject the null hypothesis.

To evaluate further the relationship between audit committee attributes on financial reporting quality in the state-owned commercial enterprises in Kenya, the following sub-hypothesis was tested.

$\mathrm{H}_{1 \mathrm{~b}}$ : Audit Committee Attributes has no significant relationship with Qualitative Characteristics in State-owned Commercial Enterprises in Kenya

\subsection{Diagnostic Tests}

\subsubsection{Multicollinearity}

Based on the results of Table 9, Variance Inflation Factor (VIF) $<10$ and the mean VIF is 1.11, an indication that the independent variables were not highly correlated, hence no existence of multicollinearity. This is an indication of the suitability of the variables for panel data regression analysis.

Table 9: Multicollinearity test results (Mean VIF=1.11)

\begin{tabular}{|l|r|r|}
\hline Variable & VIF & 1/VIF (Tolerance) \\
\hline AC_QUA & 1.23 & 0.815561 \\
\hline AC_IND & 1.09 & 0.917587 \\
\hline AC_SIZ & 1.08 & 0.923554 \\
\hline AC_MEET & 1.06 & 0.943295 \\
\hline
\end{tabular}

\subsubsection{Heteroscedasticity}

Table 10 presents the results of Breusch-Pagan/Cook-Weisberg test for heteroscedasticity with a test statistic of 1.47 ( $\mathrm{p}$-value $=0.2253$ ) which is not significant, an indication of absence of heteroscedasticity in the residual of the regression model.

Table 10: Breusch-Pagan Test for Heteroskedasticity

\begin{tabular}{|l|r|}
\hline Statistic & p-value \\
\hline 1.47 & 0.2253 \\
\hline
\end{tabular}

3.7.3 Serial Correlation Test

Wooldridge test for autocorrelation in panel data was used. Table 11 below presents the Results of Serial 
Correlation test. The p-value is 0.000 , an indication that the problem of autocorrelation is present.

Table 11: Wooldridge Test for Autocorrelation

\begin{tabular}{|l|r|}
\hline Statistic & p-value \\
\hline 1.023 & 0.0000 \\
\hline
\end{tabular}

Null Hypothesis: There is no serial correlation

3.7.4 Hausman Specification Test

To decide between fixed or random effects, Hausman specification test was used. Table 12 shows the results of

Hausman test. Based on the study results, the appropriate model is random effects model.

Table 12: Hausman Test to Choose Fixed or Random Effect

\begin{tabular}{|l|r|}
\hline Chi-square Statistic & P-Value \\
\hline 0.01 & 0.9446 \\
\hline
\end{tabular}

Null Hypothesis: The appropriate model is Random effects.

\subsection{Panel Regression Analysis}

The study examined the influence of Audit Committee Attributes on Qualitative Characteristics in State-owned Commercial Enterprises in Kenya. Results of Hausman test indicated that a random effects model was appropriate as indicated in Table 13 above.

Table 1: Results of the Random Effect model for Panel Regression Analysis, Dependent Variable: Qualitative Characteristics

VARIABLES

Model 1

AC_IND

AC_QUA

AC_SIZ

$(0.00743)$

$-0.00730$

AC MEET

Constant

Robust standard errors in parentheses

$* * * \mathrm{p}<0.01, * * \mathrm{p}<0.05, * \mathrm{p}<0.1$

The results of panel regression analysis are shown in Table 13. Random Effect model was run with the robust option to ensure that the covariance estimator could handle Heteroskedasticity of unknown form. Table 13 above provides information about model regression coefficients and the results shows that both audit committee independence $\left(A C \_I N D\right)(\beta=0.0167, p<0.05)$ and audit committee qualification $\left(A C \_Q U A\right)(\beta=-0.0142, p<0.01)$ had statistically significant and positive and negative effect on qualitative characteristics (QC) respectively for the random effect model while the results also indicate that the relationship between qualitative characteristics (QC) and audit committee size (AC_SIZ) is negative and not statistically significant $(\beta=-0.00730)$. Similarly the relationship between qualitative characteristics (QC) and audit committee Meetings (AC_MEET) $(\beta=-4.40 \mathrm{e}-05)$ is negative and not statistically significant. The value of Wald Chi-Square statistic is 8.93 while p-value is 0.0629 . The results from the Wald Chi-Square test indicate that the model as a whole is (all the predictors' regression coefficients taken jointly) not significant although Audit Committee Independence and Audit Committee Qualification are significant predictors of qualitative characteristics. R-squared $\left(\mathrm{R}^{2}\right)$ was 0.0653 which suggests that audit committee attributes accounted for $6.53 \%$ of the variance in qualitative characteristics.

Hypothesis one $\left(\mathrm{H}_{1 \mathrm{~b}}\right)$ examined the relationship between qualitative characteristics (dependent variable) and Audit Committee Attributes in the State-owned commercial enterprises in Kenya by suggesting that audit committee attributes has no significant relationship with qualitative characteristics in state-owned commercial enterprises in Kenya. Results indicate that audit committee independence (AC IND) has a significant and positive effect on qualitative characteristics while audit committee qualifications (AC $\bar{Q} U A$ ) has a negative but statistically significant effect on qualitative characteristics (QC). 6.53\% of the variance in QC is accounted for by the four audit committee attributes namely including independence, qualifications, size and number of meetings held in a 
financial year (AC_MEET). The results from the Wald Chi-Square test indicate that the model as a whole is not significant. We therefore, fail to reject the hypothesis.

In addition, a sub-hypothesis to test the relationship between audit committee attributes and timeliness reporting in the state-owned commercial enterprises was developed to aide further tests on the relationship between audit committee attributes on financial reporting quality in the state-owned commercial enterprises in Kenya. Hence the following hypothesis was tested.

$\mathrm{H}_{1 \mathrm{c}}$ : Audit Committee Attributes has no significant relationship with Timeliness Reporting in State-owned Commercial Enterprises in Kenya

\subsection{Diagnostic Tests}

\subsubsection{Multicollinearity}

Based on the results of Table 14, Variance Inflation Factor (VIF) $<10$ and the mean VIF is 1.11 an indication that the independent variables were not highly correlated, hence no existence of multicollinearity. This is an indication of the suitability of the variables for panel data regression analysis.

Table 14: Multicollinearity Test Results (Mean VIF=1.11)

\begin{tabular}{|l|r|r|}
\hline Variable & VIF & 1/VIF (Tolerance) \\
\hline AC_QUA & 1.23 & 0.815561 \\
\hline AC_IND & 1.09 & 0.917587 \\
\hline AC_SIZ & 1.08 & 0.923554 \\
\hline AC_MEET & 1.06 & 0.943295 \\
\hline
\end{tabular}

3.8.2 Heteroscedasticity

Table 15 presents the results of Breusch-Pagan/Cook-Weisberg test for Heteroskedasticity with a test statistic of $14.71(\mathrm{p}$-value $=0.0001)$ which is significant, an indication that heteroscedasticity exist in the residual of this regression model.

Table 15: Breusch-Pagan test for Heteroskedasticity

\begin{tabular}{|l|r|}
\hline Statistic & p-value \\
\hline 14.71 & 0.0001 \\
\hline
\end{tabular}

3.8.3 Serial Correlation Test

Wooldridge test for autocorrelation in panel data was used. Table 16 below presents the Results of Serial

Correlation test. The p-value is 0.000 , an indication that the problem of autocorrelation is present.

Table 16: Wooldridge Test for Autocorrelation

\begin{tabular}{|l|r|}
\hline Statistic & p-value \\
\hline 431334.283 & 0.0000 \\
\hline
\end{tabular}

Null Hypothesis: There is no serial correlation

3.8.4 Hausman Specification Test

Hausman specification test was applied to decide between fixed or random effects. Table 17 shows the results of Hausman test indicating that random effect model was appropriate for the test.

Table 27: Hausman Test to Choose Fixed or Random Effect

\begin{tabular}{|l|r|}
\hline Chi-square statistic & P-Value \\
\hline 0.02 & 0.8908 \\
\hline
\end{tabular}

Null Hypothesis: The appropriate model is Random effects.

\subsection{Panel Regression Analysis}

The study examined the influence of audit committee attributes on Timeliness Reporting as a proxy for financial reporting quality in State-owned Commercial Enterprises in Kenya. Results of Hausman test indicated that a random effects model was appropriate (Table 18). The results of panel regression analysis are shown in Table 18 below where a random fixed model was run with an option to ensure that the covariance estimator could handle heteroscedasticity of unknown form. Table 18 provides information about model regression coefficients whereby the results indicate that there is no significant relationship between Audit Committee Independence (AC_IND), Qualification (AC_QUA), Size (AC_SIZ), Meetings held in a financial year (AC_MEET) and Timeliness Reporting (T) (dependent variable). 
Table 18: Results of the Random Effect Model Panel Regression Analysis, Dependent Variable: Timeliness Reporting

\begin{tabular}{|c|c|}
\hline VARIABLES & Model 1 \\
\hline \multirow{2}{*}{ AC_IND } & 0.0980 \\
\hline & $(0.173)$ \\
\hline \multirow[t]{2}{*}{ AC_QUA } & 0.155 \\
\hline & $(0.200)$ \\
\hline \multirow[t]{2}{*}{ AC_SIZ } & -0.145 \\
\hline & $(0.163)$ \\
\hline \multirow[t]{2}{*}{ AC_MEET } & -0.00509 \\
\hline & $(0.00381)$ \\
\hline \multirow[t]{2}{*}{ Constant } & $3.834 * * *$ \\
\hline & $(0.962)$ \\
\hline Observations & 1,165 \\
\hline R-Squared & 0.0147 \\
\hline Wald chi2 (4) & 3.80 \\
\hline Prob $>$ chi 2 & 0.4336 \\
\hline Number of SOCE_ID & 108 \\
\hline
\end{tabular}

Robust standard errors in parentheses

$* * * \mathrm{p}<0.01, * * \mathrm{p}<0.05, * \mathrm{p}<0.1$

The random effects model also shows that the relationship between Timeliness Reporting and Audit Committee Size is negative and not statistically significant $(\beta=-0.145)$. Similarly the relationship between timeliness in reporting and audit committee meetings held in a year is very weak, negative and not statistically significant $(\beta=-0.00509)$. The value of Wald Chi-Square statistic is 3.80 and $p$-value is 0.4336 . The results from the Wald Chi-Square test indicate that the model as a whole is (all the predictors' regression coefficients taken jointly) not statistically significant. R-squared $\left(\mathrm{R}^{2}\right)$ was 0.0147 which suggests that audit committee attributes accounted for $1.47 \%$ of the variance in Timeliness Reporting used as a proxy of financial reporting quality.

Hypothesis one $\left(\mathrm{H}_{1 \mathrm{c}}\right)$ examined the relationship between Timeliness Reporting (dependent variable) and audit committee attributes in the state-owned commercial enterprises in Kenya by suggesting that Audit committee attributes has no significant relationship with timeliness reporting in state-owned commercial enterprises in Kenya. Results of this study indicate that audit committee attributes have no significant effect on timeliness reporting. The results from the Wald Chi-Square test also indicate that the whole model is not significant. We therefore, fail to reject the hypothesis.

\section{Summary of Findings and Conclusion}

The objective of the study examined the relationship between Audit Committee Attributes and Financial Reporting Quality in State-owned Commercial Enterprises in Kenya. The study used Audit Committee Independence, Size, Qualification and Meetings held in a year as indicators of the Audit Committee Attributes while Accrual Quality, Qualitative Characteristics and Timeliness reporting were used as barometers of Financial Reporting Quality. While the Audit Committee Independence shows significant positive relationship with Financial Reporting Quality in State-owned Commercial Enterprises in Kenya $(\beta=0.0148, p<0.01)$, Audit Committee Qualification equally reveals a significant negative relationship with Financial Reporting Quality $(\beta=-0.0138, p<0.01)$. However, the results indicate that Audit Committee Size and Audit Committee Meetings held in a year have negative and nonstatically significant relationship with Financial Reporting Quality. The results from the Wald Chi-Square test indicate that the model as a whole is (all the predictors' regression coefficients taken jointly) significant with Rsquared $\left(\mathrm{R}^{2}\right)$ of 0.0695 which suggests that Audit Committee Attributes accounts for $6.95 \%$ of the variance in financial reporting quality.

Further analysis show a statistically significant positive and negative effect of both Audit Committee Independence (AC_IND) $(\beta=0.0167, \mathrm{p}<0.05)$ and Audit Committee Qualification (AC_QUA) $(\beta=-0.0142$, $\mathrm{p}<0.01)$ respectively on Qualitative Characteristics while Audit Committee Size $(\beta=-0.00730, p>0.05)$ and Audit Committee Meetings held (AC_SIZ) $(\beta=-0.000044, p>0.05)$ indicates negative and not statistically significant $(\beta=$ $-0.00730, p>0.05$ ) effect on Qualitative Characteristic in State-owned Commercial Enterprises in Kenya. The results from the Wald Chi-Square test indicate that the model as a whole is (all the predictors' regression coefficients taken jointly) not significant although Audit Committee Independence and Audit Committee Qualification are significant predictors of Qualitative Characteristics. R-squared $\left(\mathrm{R}^{2}\right)$ was 0.0653 which suggests that audit committee characteristics accounts for $6.53 \%$ of the variance in qualitative characteristics. We therefore, fail to reject the hypothesis. Results of this study indicate that Audit Committee Independence (AC_IND) has a significant and positive effect on Qualitative Characteristics while Audit Committee Qualifications (AC_QUA) 
has a negative but statistically significant effect on Qualitative Characteristics in the State-owned Commercial Enterprises in Kenya.

Furthermore, the results reveal that there is no significant relationship between Audit Committee Independence $(\beta=0.0980, p>0.05)$, Qualification $(\beta=0.200, p>0.05)$, Size $(\beta=-0.145, p>0.05)$, Meetings held in a financial year $(\beta=-0.00509, p>0.05)$ and Timeliness Reporting in State-owned Commercial Enterprises in Kenya. The random effects model also shows that the relationship between Timeliness Reporting and Audit Committee Size is negative and not statistically significant $(\beta=-0.145, \mathrm{p}>0.05)$. The results from the Wald Chi-Square test indicate that the model as a whole is (all the predictors' regression coefficients taken jointly) not statistically significant with R-squared $\left(\mathrm{R}^{2}\right)$ of 0.0147 which suggests that Audit Committee Characteristics accounts for $1.47 \%$ of the variance in Timeliness Reporting. We therefore, fail to reject the hypothesis.

Finally an additional test examined the influence of audit committee attributes on accrual quality in Stateowned Commercial Enterprises in Kenya. The results of the test indicate that there is negative and statistically significant relationship between Audit Committee Qualification $(\beta=35.54, p<0.05)$, Audit Committee Size $(\beta=$ 181.0, $\mathrm{p}<0.01)$, Audit Committee Meetings held in a year $(\beta=89.42, \mathrm{p}<0.05)$ and Accrual Quality conversely the relationship between Accrual Quality and Audit Committee Independence was negative and statistically significant $(\beta=-30.64, p<0.05)$. R-squared $\left(R^{2}\right)$ was 0.064 which suggests that audit committee attributes accounted for $6.4 \%$ of the variance in the accrual quality which is a measure of financial reporting quality. The results of the study however, indicate that audit committee attributes have a significant relationship with accrual quality and we therefore, reject the null hypothesis (Table 19).

The results reveal that that audit committee attributes has statistically significant relationship with financial reporting quality of State-owned Commercial Enterprises in Kenya. Results further indicate audit committee independence had statistically significant and negative relationship whereas audit committee qualification, size and meetings held in a financial year had statistically significant and positive relationship with accrual quality which was a measure of financial reporting quality. In addition, audit committee independence and qualification had statistically significant positive and negative relationship with qualitative characteristics. However, it was also evident that audit committee attributes had no significant relationship with timeliness reporting. It is therefore, concluded that audit committee attributes impacted financial reporting quality.

Table 19: Summary of Research Objective, Hypotheses and Test Results

\begin{tabular}{|c|c|c|c|}
\hline $\begin{array}{c}\text { Specific } \\
\text { Research } \\
\text { Objectives }\end{array}$ & Hypothesis & Results & Interpretation \& Comments \\
\hline \multirow{4}{*}{$\begin{array}{l}\text { Determine the } \\
\text { relationship } \\
\text { between Audit } \\
\text { Committee } \\
\text { Attributes and } \\
\text { Financial } \\
\text { Reporting } \\
\text { Quality in } \\
\text { State-owned } \\
\text { Commercial } \\
\text { Enterprises in } \\
\text { Kenya }\end{array}$} & $\begin{array}{l}\text { Ho1: Audit Committee } \\
\text { Attributes has no } \\
\text { significant relationship } \\
\text { with Financial Reporting } \\
\text { Quality of State-owned } \\
\text { Commercial Enterprises } \\
\text { in Kenya }\end{array}$ & $\begin{array}{l}\beta=0.0148, \mathrm{p}<0.01 ; \beta=- \\
0.0138, \mathrm{p}<0.01 ; \mathrm{R}^{2}= \\
0.0695 ; \\
H_{01} \text { is rejected }\end{array}$ & $\begin{array}{l}\text { The relationship between Audit } \\
\text { Committee Attributes and } \\
\text { Financial Reporting Quality of } \\
\text { State-owned Commercial } \\
\text { Enterprises in Kenya is } \\
\text { statistically significant. }\end{array}$ \\
\hline & $\begin{array}{l}\text { Ho1a: Audit Committee } \\
\text { Attributes has no } \\
\text { significant relationship } \\
\text { with Accrual Quality of } \\
\text { State-owned } \\
\text { Commercial Enterprises } \\
\text { in Kenya }\end{array}$ & $\begin{array}{l}\beta=-30.64, p<0.05 ; \beta= \\
35.54, p<0.05 ; \beta=181.0 \\
\mathrm{p}<0.01 ; 89.42, p<0.05 \\
\mathrm{R}^{2}=0.064 \\
\text { Ho1 }_{\text {a is rejected }}\end{array}$ & $\begin{array}{l}\text { The relationship between Audit } \\
\text { Committee Attributes and Accrual } \\
\text { Quality of State-owned } \\
\text { Commercial Enterprises in Kenya } \\
\text { is statistically significant. }\end{array}$ \\
\hline & $\begin{array}{l}\text { Ho1b: Audit Committee } \\
\text { Attributes has no } \\
\text { significant relationship } \\
\text { with Qualitative } \\
\text { Characteristics of State- } \\
\text { owned Commercial } \\
\text { Enterprises in Kenya }\end{array}$ & $\begin{array}{l}\beta=0.0167, p<0.05 ; \beta=- \\
0.0142, p<0.01 ; \beta=- \\
0.00730 ; R^{2}=0.0653 ; \beta=- \\
4.40 \mathrm{e}-05 \\
\text { Fail to reject } \mathbf{H}_{01 b}\end{array}$ & $\begin{array}{l}\text { The relationship between Audit } \\
\text { Committee Attributes and } \\
\text { Qualitative Characteristics of } \\
\text { State-owned Commercial } \\
\text { Enterprises in Kenya is not } \\
\text { statistically significant }\end{array}$ \\
\hline & $\begin{array}{l}\text { Ho1c: Audit Committee } \\
\text { Attributes has no } \\
\text { significant relationship } \\
\text { with Timeliness } \\
\text { Reporting of State- } \\
\text { owned Commercial } \\
\text { Enterprises in Kenya }\end{array}$ & $\begin{array}{l}\beta=-0.145, p>0.01 ; \\
\beta=0.0980, p>0.01 ; \\
\beta=0.155, p>0.01 ; \beta=- \\
0.00509, p>0.01 ; \\
\text { Fail to reject } \mathbf{H}_{01 c}\end{array}$ & $\begin{array}{l}\text { The relationship between Audit } \\
\text { Committee Attributes and } \\
\text { Timeliness Reporting of State- } \\
\text { owned Commercial Enterprises in } \\
\text { Kenya is not statistically } \\
\text { significant. }\end{array}$ \\
\hline
\end{tabular}




\section{References}

Abbott, L. J., Park, Y. \& Parker, S. (2000). The Effects of Audit Committee Activity and Independence on Corporate Fraud. Managerial Finance, 26(11), 55-67.

Abbott, I. J., Parker, S., Peters, G., \& Raghunandan, K. (2003). An Empirical Investigation of Audit Fees, Nonaudit Fees and Audit Committees. Contemporary Accounting Research, 20(2), 215-234.

Archambeault, D., \& DeZoort, F. (2001). Auditor Opinion Shopping and the Audit Committee: An analysis of suspicious auditor switches. International Journal of Auditing, 5, 33-52.

Beasley, M. S. (1996). An Empirical Analysis of the Relation between the Board of Director Composition and Financial Statement Fraud. Accounting Review, 71, 443-466.

Bedard, J., \& Gendron, Y. (2010). Strengthening the Financial Reporting System: Can Audit Committees Deliver? International Journal of Auditing, 14(2), 174-210.

Bedard, J., Chtourou, S.M. \& Courteau, L. (2004). The Effect of audit committee expertise, independence and activity on aggressive earnings management. Auditing: A Journal of Practice and Theory, 23(2), 13-35.

Bell, A. \& Jones, K. (2015). Explaining fixed effects, random effects modeling of time-series cross-sectional and panel data. Political Science Research Methods, 3(1), 133-153.

Breitung, J. \& Das, S. (2005). Panel data unit root tests under cross-sectional dependence. Statistica Neerlandica, 59: 414-433.

Bronson, S. N., Carcello, J. V. \& Raghunandan, K. (2006). Firm characteristics and voluntary management reports on internal control. Auditing: A journal of Practice \& Theory 25(2), S. 25-39.

Capital Markets Act 485A regulations 2011.

Chen, J., Duh, R., \& Shiue, F. N. (2008). The Effect of Audit Committees on Earnings-Return Association: Evidence from Foreign Registrants in the United States. Corporate Governance: An International Review, 16 (1), 32-40.

Collier, P. \& Gregory, A. (1998). Audit Committee Activity and Agency. Journal of Accounting and Public Policy. Winter: $311-32$

Cooper, D. R. \& Schindler, P.S. (2006). Business research methods ( $9^{\text {th }}$ ed.). Boston: MA: McGraw-Hill/Irwin.

Creswell, J.W. (2009). Research design: Qualitative, quantitative, and mixed methods approaches. Thousand Oaks, CA: Sage Publications, Incorporated.

Dechow, P. M., \& Dichev, I. D. (2002. The Quality of Accruals and Earnings: The Role of Accrual Estimation Errors. The Accounting Review, 77, 35-59.

DeZoort, F. T., \& A. T. Lord. (1997). A review and synthesis of pressure effects research in accounting. Journal of Accounting Literature 16: 28-85.

DeZoort, F.T., Hermanson, D.R., Archambeault, D.S. \& Reed, S.A. (2002). Audit committee effectiveness: A synthesis of the empirical audit committee literature. Journal of Accounting Literature, 21, 38-75.

Doyle, J., Ge, W. \& McVay, S. (2007). Determinants of weaknesses in internal control over financial reporting. Journal of Accounting and Economics, 44(1), 193-223.

Felo, J. A., Krishnamurthy, S. \& Solieri, S. A. (2003). Audit committee characteristics and the perceived quality of financial reporting: An Empirical Analysis. SSRN-id401240.

Fitrianto, A \& Musakkal, N.F.K. (2016). Panel Data Analysis for Sabah Construction Industries: Choosing the Best Model. $7^{\text {th }}$ International Economics and Business Management Conference, $5^{\text {th }} \& 6^{\text {th }}$ October, 2015 , available at: http://creativecommons.org/licenses/by-nc-nd/4.0/

Healy, P. \& K. Palepu (1995). Information asymmetry, corporate disclosure, and the capital markets: a review of the empirical disclosure literature. Journal of Accounting and Economics, 31(1-3): 405-440.

IASB (2008). Exposure Draft on an improved Conceptual Framework for Financial Reporting: The Objective of Financial Reporting and Qualitative Characteristics of Decision-useful Financial Reporting Information. London.

IASB (2010). Revised Constitution March. IFRS Foundation. <http://www.iasplus.com>

Isakulchai, M. K. (2015). The Impact of the Audit Committee Effectiveness and Audit Quality on Financial Reporting Quality of listed company in Stocks Exchange of Thailand. Integrative Business \& Economics, 4(2), 328-341.

Kalbers, L.P. \& Fogarty, T. J. (1993). Audit Committee Effectiveness: An Empirical Investigation of the Contribution of Power. Auditing: Journal of Practice and Theory, 12(1), 24-49.

Kusnadi, Y., Leong, K., Suwardy, T., \& Wang, J. (2015). Audit Committees and Financial Reporting Quality in Singapore. Journal of Business Ethics, 139(1), 197-214.

Martinez-Ferrero, J. (2014). Consequences of financial reporting quality on corporate performance: Evidence at the international level. Estudios de Economia, 41(1) 49-88.

McDaniel, L., R.D. Martin \& L.A. Maines (2002). Evaluating Financial Reporting Quality: The Effects of Financial Expertise vs. Financial Literacy. The Accounting Review. 77 (Supplement): 139-167.

Mohiuddin, Md. And Karbhari, Y. (2010). Audit Committee Effectiveness: A critical Literature Review. AIUB 
Journal of Business and Economics, 9(1), 97-125.

Ogoro, G. O. \& Simiyu, C. N. (2015). Effectiveness of Audit Committees in the Public Sector: A Case of Parastatals in Kenya. Research Journal of Finance and Accounting, 6(4), 56-65.

Omoro, N. O. (2014). Demographic Diversity of Top Management Team, Corporate Voluntary Disclosure, Discretionary Accounting Choices and Financial Reporting Quality in Commercial State Corporations in Kenya. Thesis submitted in partial fulfillment of the requirements of the Award of the Degree of Doctor of Philosophy in Business administration at the University of Nairobi, School of Business. Available at http://hdl.handle.net/11295/76994

Outa, E. R. (2011). The Impact of International Financial Reporting Standards (IFRS) Adoption on the Accounting Quality on Listed Companies in Kenya. International Journal of Accounting \& Financial Reporting. 1(1), $212-214$

Sarbanes-Oxley Act. (2002). Sarbanes-Oxley Act of 2002. Public Law 107-204, 116 Stat 745. Washington, DC: Government Printing Office. Available at https://pcaobus.org > Documents $>$ PDFs

Saunders, M., \& Thornhill, A. (2012). Research methods for business students: Essex: Pearson Education Limited.

SEC (2003). Management's Reports on Internal Control over Financial Reporting and Certification Disclosure in Exchange Act Periodic Reports, Final Rule 33-8238 (June 5), Washington, D.C.

Sehu, U.H \& Bello, A. (2013). Firm characteristics and financial reporting quality in listed manufacturing firms in Nigeria. International Journal of Accounting, Banking and Management, 1(6), 47-63.

Shapiro, S.S. \& Francia, R.S. (1972). An approximate analysis of variance test for normality. Journal of the American Statistical Association, 67(337): 215-216: DOI: 10.1080/01621459.1972.10481232.

Shapiro, S.S. \& Wilk, M.B. (1965). An analysis of variance test for normality (complete samples). An approximate analysis of variance test for normality. Biometrika 527(3/4): 591-611.

Siti, R. I. \& Nazli, A. M. G (2012). Audit committee effectiveness and timeliness of reporting: Indonesian evidence. Managerial Auditing Journal, 27(4), 403-424.

Song, J. \& Windram, B. (2000). Benchmarking Audit Committee Effectiveness in the UK. Available at SSRN: http://dx.doi.org/10.2139/ssrn.249865

Turley, S., \& Zaman, M. (2007). Audit Committee Effectiveness: Informal Processes and Behavioral Effects. Accounting, Auditing and Accountability Journal, 20 (5.)

Woodlock, P. (2006). Building an effective audit committee. Journal of Corporate Accounting \& Finance, 17(4), 51-56. 